\title{
PENGARUH PENGENDALIAN INTERNAL TERHADAP PENCEGAHAN FRAUD MELALUI AKUNTABILITAS PUBLIK SEBAGAI VARIABEL INTERVENING
}

\author{
Anissa Hakim Purwantini \\ Siti Noor Khikmah \\ Universitas Muhammadiyah Magelang \\ e-mail: aha.ansa@gmail.com
}

\begin{abstract}
This research is aimed to investigate whether internal control have significant effect to fraud prevention using public accountability as intervening variabel. The data in this research is the primary data, which obtained by distributing questionnaires directly to respondents, Inspectorate auditors of the city as ex-Kedu residency. Amount of sampel is 59 Inspectorate auditors that be selected by using purposive sampling method. Hypothesis testing was done by path analysis. This research shows that internal control significantly affect to public accountability and fraud prevention. Using path analysis found that internal control can directly influence to fraud prevention and also have indirectly affect from internal control to public accountability (as intervening) and to fraud prevention. The value of $R^{2}$ public accountability is $56.9 \%$, it means that public accountability level is explained by the variable of internal control $56.9 \%$, while the other $43.1 \%$ is explained by other variables. However, the value of $R^{2}$ fraud prevention is $75.8 \%$, it means that fraud prevention level is explained by the variable of internal control $75.8 \%$, while the other $24.2 \%$ is explained by variables excluded from the model.
\end{abstract}

Keywords: internal control, public accountability, fraud prevention

\section{PENDAHULUAN}

Timbulnya permasalahan menyangkut tindak pidana korupsi yang berujung pada kerugian negara masih dialami oleh pemerintah daerah di lingkup eks-Karesidenan Kedu saat ini. Beberapa temuan kasus korupsi yang dipublikasikan oleh media menyangkut tindak pidana tersebut seperti dilansir dari suaramerdeka.com yang memberitakan bahwa Kepala Dinas Kesehatan Kota Magelang terlibat tindak pidana korupsi dalam proyek sistem informasi manajemen terpadu di RSUD Tidar Magelang tahun 2001 - 2005 yang merugikan negara sebesar Rp 1,3 miliar. Kasus korupsi lainnya dilakukan oleh Mantan Kepala Dinas Kesehatan Purworejo yang terlibat kasus korupsi alat kesehatan sehingga merugikan negara sekitar Rp 2,138 miliar (infokorupsi.com). Mantan Kepala Disdikpora Kabupaten Wonosobo juga terlibat kasus korupsi pengadaan buku ajar tahun 2004-2005 yang menyebabkan kerugian negara mencapai Rp7,3 miliar (antarajateng.com). Cakupan wilayah eks-Karesidenan Kedu terdiri dari enam kota/kabupaten. Dari keenam kota/ 
kabupaten di wilayah eks-Karesidenan Kedu tersebut hanya Kabupaten Kebumen saja yang memperoleh opini Wajar Tanpa Pengecualian atas Laporan KeuanganPemerintah Daerah tahun 2011 dan 2012 dari BPK RI Perwakilan Jawa Tengah (www.beritakebumen.info).

Berdasarkan temuan kasus-kasus tersebut, menunjukkan bahwa pengelolaan keuangan pemerintah daerah masih belum baik. Fajarina, dkk (2012) mengemukakan bahwa penerapan otonomi daerah mengakibatkan pendelegasian wewenang pemerintah pusat banyak dilimpahkan ke daerah kabupaten/kota sehingga berpotensi memindahkanfraud dari pusat ke daerah juga lebih banyak. Maraknya berita mengenai indikasi fraud di dalam pengelolaan keuangan negara semakin membuat sadar bahwa perlu dilakukan tindakan untuk membenahi ketidakberesan tersebut. Menurut Ruslan (2011), diperlukan upaya yang lebih sistematis dalam menanggulangi terjadinya fraud dengan menggunakan pemikiran yang jelas. Hal pertama yang harus diidentifikasikan adalah penyebab utama terjadinya fraud sehingga bisa dirumuskan strategi yang tepat untuk menghilangkan atau paling tidak mengurangi intensitas yang ditimbulkan dari fraud tersebut. Hal ini kemudian yang disebut sebagai pencegahan fraud.

Rachman (2012) mengungkapkan bahwa upaya mencegah fraud, dimulai dari pengendalian internal. Adanya pengendalian internal yang baik akan mengurangi tindak kecurangan. Beberapa bukti empiris berikut ini menjelaskan pengendalian intern dengan kecurangan akuntansi. Pertama, Smith, et al (1997) menguji interaksi evaluasi pengendalian intern dengan pengujian substantif dalam model pendeteksian kecurangan akuntansi dari perspektif auditor. Hasil penelitiannya menunjukkan bahwa kecurangan akuntansi diindikasikan dengan pengendalian intern dari organisasi yang lemah. Penelitian Reinstein and Bayou (1998) menjelaskan bahwa kecurangan akuntansi dapat terjadi bila pengendalian intern lemah. Pengendalian intern yang kuat mencegah manajemen untuk melakukan kecurangan akuntansi (Matsumura and Robert, 1992). Temuan empiris Hermiyetti (2011), Kumalasari (2011) dan Fajarina, dkk (2012) menunjukkan bahwa pengendalian intern berpengaruh positif terhadap pencegahan fraud. Namun demikian, Wilopo (2008) tidak menemukan hubungan pengendalian intern birokrasi dengan kecurangan akuntansi pemerintah.

Seperti yang dinyatakan Chan (2003) bahwa pejabat pemerintah seharusnya transparan dalam menyampaikan informasi yang terkait dengan segala tindakannya. Namun demikian secara rasional mereka tidak akan secara suka rela menyampaikan informasi secara berlebihan melebihi yang diminta Menurut Wilopo (2008), upaya untuk tidak memberikan informasi secara transparan menimbulkan adanya dugaan information asymmetry yang berujung pada kecurangan akuntansi di pemerintahan yang menjadi alat pejabat pemerintah melakukan korupsi. Oleh karena itu, pengelolaan pemerintah daerah harus akuntabel dan diawasi (checks and balances) untuk memastikan bahwa pengelolaan dilakukan dengan penuh kepatuhan. Setiawan (2012) mengemukakan bahwa semakin baik akuntabilitas suatu pemerintah daerah berarti semakin sedikit terjadinya permasalahan information asymmetry dan semakin sedikit peluang terjadinya fraud oleh pihak pemerintah daerah (agent). Penelitian Adefila and Adeoti (2006) menemukan bahwa akuntabilitas merupakan metode yang paling baik untuk mencegah fraud.

Berdasarkan uraian yang telah dijelaskan, penelitian ini akan menguji pengaruh pengendalian intern terhadap akuntabilitas publik dan pencegahan fraud serta bagaimana pengaruh pengendalian intern melalui akuntabilitas publik (sebagai variabel intervening) terhadap 
pencegahan fraud di instansi pemerintah daerah menurut persepsi auditor Inspektorat se-eks Karesidenan Kedu.

\section{REVIEW LITERATUR DAN HIPOTESIS}

\section{Agency Theory}

Menurut agency theory dalam penelitian Jensen dan Meckling (1976), mendefinisikan hubungan keagenan sebagai sebuah kontrak dimana satu atau lebih (principal) menyewa orang lain (agent) untuk melakukan beberapa jasa untuk kepentingan mereka dengan mendelegasikan beberapa wewenang pembuatan keputusan kepada agen. Moe (1984) menjelaskan konsep ekonomika organisasi sektor publik dengan menggunakan agency theory. Berdasarkan agency theory dapat digambarkan bahwa hubungan rakyat dengan pemerintah dapat dikatakan sebagai hubungan keagenan, yaitu hubungan yang timbul karena adanya kontrak yang ditetapkan oleh rakyat (sebagai principal) yang menggunakan pemerintah (sebagai agent) untuk menyediakan jasa yang menjadi kepentingan rakyat.

Agency theory beranggapan bahwa banyak terjadi information asymmetry antara pihak agent (pemerintah) yang mempunyai akses langsung terhadap informasi dengan principal (masyarakat). Menurut Wilopo (2008), upaya untuk tidak memberikan informasi secara transparan menimbulkan dugaan adanya information asymmetry. Adanya information asymmetry inilah yang memungkinkan terjadinya fraud oleh agent (pemerintah). Untuk mengantisipasi tindakan fraud yang dapat dilakukan oleh pihak agent maka harus dilakukan pengawasan terhadap kinerja agent dengan menerapkan sistem pengendalian yang efektif. Sistem pengendalian tersebut diharapkan mampu mengurangi adanya perilaku menyimpang dalam sistem pelaporan, termasuk adanya kecurangan akuntansi. Mohamad dkk (2004), dalam Kristianto (2011) berpendapat bahwa akuntabilitas muncul sebagai jawaban terhadap permasalahan information asymmetry. Semakin baik akuntabilitas suatu pemerintah berarti semakin sedikit terjadinya information asymmetry dan semakin sedikit peluang terjadinya fraud.

\section{Pengendalian Intern}

Menurut Peraturan Pemerintah Nomor 60 Tahun 2008 Pasal 1 ayat (1), pengendalian intern merupakan proses yang integral pada tindakan dan kegiatan yang dilakukan secara terus menerus oleh pimpinan dan seluruh pegawai, untuk memberikan keyakinan memadai atas tercapainya tujuan organisasi melalui kegiatan yang efektif dan efisien, keandalan pelaporan keuangan, pengamanan aset negara, dan ketaatan terhadap peraturan perundang-undangan. Unsur Pengendalian Intern dalam PP Nomor 60 Tahun 2008 tentang Sistem Pengendalian Intern Pemerintah, terdiri dari lima komponen yang saling terkait, yaitu:

a. Lingkungan pengendalian

Komponen lingkungan pengendalian mengharuskan Pimpinan Instansi Pemerintah menciptakan dan memelihara lingkungan pengendalian yang menimbulkan perilaku positif dan kondusif untuk penerapan Sistem Pengendalian Intern dalam lingkungan kerjanya, melalui: (1) Penegakan integritas dan nilai etika; (2) Komitmen terhadap kompetensi; (3) Kepemimpinan yang kondusif; (4) Pembentukan struktur organisasi yang sesuai dengan kebutuhan; (5) Pendelegasian wewenang dan tanggungjawab yang tepat; (6) Penyusunan dan penerapan kebijakan yang sehat tentang pembinaan sumber daya manusia; (7) Perwujudan peran aparat pengawasan intern pemerintah yang efektif.

b. Penilaian risiko

Pengendalian intern harus memberikan penilaian atas risiko yang dihadapi unit organisasi baik dari luar maupun dari dalam. 
Penilaian risiko merupakan identifikasi dan analisis risiko yang dapat menghambat atau berhubungan dengan pencapaian tujuan perusahaan, serta menentukan cara bagaimana risiko tersebut ditangani. Pimpinan Instansi Pemerintah wajib melakukan penilaian risiko. Penilaian risiko terdiri atas identifikasi risiko dan analisis risiko. Pimpinan instansi pemerintah menetapkan tujuan instansi pemerintah dan tujuan pada tingkatan kegiatan dengan berpedoman pada peraturan perundang-undangan dalam rangka penilaian risiko.

c. Kegiatan pengendalian

Kegiatan pengendalian adalah tindakan yang diperlukan untuk mengatasi risiko serta penetapan dan pelaksanaan kebijakan dan prosedur untuk memastikan bahwa tindakan mengatasi risiko telah dilaksanakan secara efektif. Kegiatan pengendalian mewajibkan Pimpinan Instansi Pemerintah untuk menyelenggarakan kegiatan pengendalian sesuai dengan ukuran, kompleksitas, dan sifat dari tugas dan fungsi Instansi Pemerintah yang bersangkutan. Penyelenggaraan kegiatan pengendalian ini meliputi pengendalian pengolahan informasi, pemisahan tugas, pengendalian fisik dan review atas kinerja. Kegiatan pengendalian harus efisien dan efektif dalam pencapaian tujuan organisasi.

d. Informasi dan komunikasi

Komponen informasi dan komunikasi menjelaskan bahwa sistem informasi sangat penting bagi keberhasilan atau peningkatan mutu operasional organisasi. Informasi adalah data yang telah diolah yang dapat digunakan untuk pengambilan keputusan penyelenggaraan tugas dan fungsi instansi pemerintah. Komunikasi adalah proses penyampaian pesan atau informasi dengan menggunakan simbol atau gambar. Komunikasi atas informasi wajib diselenggarakan secara efektif. Pimpinan instansi menyelenggarakan komunikasi yang efektif dengan menyediakan dan memanfaatkan berbagai bentuk dan sarana komunikasi serta mengelola, mengembangkan, dan memperbaharui sistem informasi secara terus-menerus.

e. Pemantauan

Pemantauan pengendalian intern adalah proses penilaian atas mutu kinerja Sistem Pengendalian Intern dan proses yang memberikan keyakinan bahwa temuan audit dan evaluasi lainnya segera ditindaklanjuti. Pemantauan harus dapat menilai kualitas kinerja dari waktu ke waktu dan memastikan bahwa rekomendasi hasil audit dan review lainnya dapat segera ditindaklanjuti.

\section{Akuntabilitas Publik}

Salah satu pilar utama sistem good governance adalah akuntabilitas. Fenomena yang terjadi dalam perkembangan sektor publik di Indonesia paska reformasi adalah menguatnya tuntutan akuntabilitas atas lembagalembaga publik, baik di pusat maupun daerah. Menurut Mahsun (2009:45) akuntabilitas publik merupakan pemberian informasi dan disclosure atas aktivitas dan kinerja finansial pemerintah kepada pihak-pihak yang berkepentingan. Akuntabilitas publik yang harus dijalankan oleh organisasi sektor publik mempunyai beberapa dimensi. Ellwood (2003) dalam (Mardiasmo, 2005:22) menjelaskan terdapat empat dimensi akuntabilitas yang harus dipenui oleh organisasi sektor publik, yaitu:

a. Akuntabilitas kejujuran dan akuntabilitas hukum

Akuntabilitas kejujuran terkait dengan penyalahgunaan jabatan (abuse of power), sedangkan akuntabilitas hukum terkait dengan jaminan adanya kepatuhan terhadap aturan hukum dan aturan lain yang disyaratkan dalam penggunaan sumber dana publik. 
b. Akuntabilitas proses (process accountability) Akuntabilitas proses terkait apakah prosedur yang digunakan dalam melaksanakan tugas sudah cukup baik dalam hal kecukupan sistem informasi akuntansi, sistem informasi manajemen, dan prosedur administrasi. Akuntabilitas proses termanifestasi melalui pemberian pelayanan publik yang cepat, responsif, dan murah biaya. Pengawasan dan pemeriksaan terhadap pelaksanaan akuntabilitas proses dapat dilakukan, misalnya dengan memeriksa ada tidaknya mark up dan pungutan-pungutan lain di luar yang ditetapkan, serta sumbersumber inefisiensi dan pemborosan yang menyebabkan mahalnya biaya pelayanan publik dan kelambanan dalam pelayanan.

c. Akuntabilitas program (program accountability)

Akuntabilitas program terkait dengan pertimbangan apakah tujuan yang ditetapkan dapat dicapai atau tidak, dan apakah telah mempertimbangkan alternatif program yng memberikan hasil yang optimal dengan biaya minimal.

d. Akuntabilitas kebijakan (policy accountability)

Akuntabitas kebijakan terkait dengan pertanggungjawaban baik pusat maupun daerah atas kebijakan-kebijakan yang diambil pemerintah terhadap DPR/DPRD dan masyarakat luas.

\section{Pencegahan Fraud}

Pencegahan fraud pada umumnya adalah aktivitas yang dilaksanakan dalam hal penetapan kebijakan, sistem dan prosedur yang membantu bahwa tindakan yang diperlukan sudah dilakukan dewan komisaris,manajemen, dan personil lain dalam perusahaan untuk dapat memberikan keyakinan memadai dalam mencapai tujuan organisasi yaitu: efektivitas dan efisiensi operasi, keandalan laporan keuangan, dan kepatuhan terhadap hukum dan peraturan yang berlaku (COSO,1992:13). Auditor internal bertanggungjawab untuk membantu pencegahan fraud dengan jalan melakukan pengujian (test) atas kecukupan dan keefektifan sistem pengendalian intern, dengan mengevaluasi seberapa jauh risiko yang potensial (potential risk) telah diidentifikasi (Nurdin, 2012). Menurut Rezaee dan Richard (2010:48) menjelaskan ada tiga unsur yang harus diperhatikan oleh pihak manajemen perusahaan bila ingin mencegah terjadinya tindakan fraud, yaitu:

a. Menciptakan dan mengembalikan budaya yang menghargai kejujuran dan nilai-nilai etika yang tinggi, meliputi:

1) Setting at the top, penelaahan peraturan perundang-undangan yang bertujuan untuk memperoleh pengertian mengenai peraturan-peraturan yang bersifat umum yang ditetapkan pada semua instansi.

2) Merekrut dan mempromosikan karyawan yang tepat, yaitu setiap perekrutan staff dilakukan penyeleksian dan ditempatkan sesuai bidang keahliannya.

3) Pelatihan, setiap anggota organisasi seharusnya mengikuti pelatihan untuk meningkatkan profesionalisme dan kualitas kerja.

4) Disiplin, yaitu mentaati peraturanperaturan yang telah dibuat.

b. Penerapan dan evaluasi Proses Pengendalian anti kecurangan, yaitu:

1) Mengidentifikasi dan mengukur risiko fraud

2) Pengurangn risiko fraud

3) Implementasi dan monitoring pengendalian intern.

c. Pengembangan Proses Pengawasan (Oversight Process), untuk mencegah dan menangkal fraud secara efektif instansi hendaknya mempunyai fungsi pengawasan yang tepat. 


\section{Pengaruh Pengendalian Intern terhadap Akuntabilitas Publik}

Akar permasalahan rendahnya akuntabilitas di Indonesia adalah kegagalan Kementrian, Lembaga Negara, BUMN/BUMD dan pemerintah daerah dalam mengimplementasikan Sistem Pengendalian Intern Pemerintah (www. jurnalparlemen.com). Untuk mencapai akuntabilitas pemerintah daerah wajib melakukan pengendalian atas penyelenggaraan kegiatan pemerintah yang berpedoman pada PP Nomor 60 Tahun 2008. Idris (2012) dalam penelitiannya menemukan bahwa pengendalian intern memiliki pengaruh positif secara langsung dan signifikan terhadap akuntabilitas. Berdasarkan uraian tersebut maka hipotesis yang diajukan dalam penelitian ini adalah:

H1 : Pengendalian intern berpengaruh positif terhadap akuntabilitas publik.

\section{Pengaruh Pengendalian Intern terhadap Pencegahan Fraud}

Menurut Siti dan Ely (2010:64) dalam Kumalasari (2011) menyatakan bahwa pengendalian intern yang secara khusus ditujukan untuk menangani fraud merupakan suatu sistem dengan proses dan prosedur yang bertujuan khusus, dirancang dan dilaksanakan untuk tujuan utama, untuk mencegah dan menghalangi (dengan membuat jera) terjadinya kecurangan. Lemahnya pengendalian intern merupakan penyebab utama terjadinya kecurangan. Pengendalian intern yang baik/tinggi akan berpengaruh terhadap baiknya pencegahan fraud, demikian sebaliknya bila pengendalian intern rendah/buruk maka akan melemahkan pencegahan fraud.

Smith, et al (1997) menguji interaksi evaluasi pengendalian intern dengan pengujian substantif dalam model pendeteksian kecurangan akuntansi dari perspektif auditor. Hasil penelitiannya menunjukkan bahwa kecurangan akuntansi diindikasikan dengan pengendalian intern dari organisasi yang lemah. Penelitian Reinstein and
Bayou (1998) menjelaskan bahwa kecurangan akuntansi dapat terjadi bila pengendalian intern lemah. Pengendalian intern yang kuat mencegah manajemen untuk melakukan kecurangan akuntansi (Matsumura and Robert, 1992). Temuan empiris Hermiyetti (2011) dan Fajarina, dkk (2012) menunjukkan bahwa komponen pengendalian intern berpengaruh positif terhadap pencegahan fraud. Penelitian yang dilakukan oleh Kumalasari (2011) menemukan bukti empiris bahwa pengendalian intern mempunyai pengaruh yang signifikan dan positif terhadap pencegahan fraud. Semakin baik pengendalian internal birokrasi pemerintahan, semakin rendah kecurangan akuntansi pemerintahan. Berdasarkan penelitian sebelumnya tersebut, maka hipotesis kedua yang akan diuji dalam penelitian ini adalah:

H2 : Pengendalian intern berpengaruh positif terhadap pencegahan fraud.

\section{Pengaruh Akuntabilitas Publik terhadap hubungan antara Pengendalian Intern dengan Pencegahan Fraud}

Menurut Wilopo (2008), upaya untuk tidak memberikan informasi secara transparan menimbulkan adanya dugaan information asymmetry yang berujung pada kecurangan akuntansi di pemerintahan yang menjadi alat pejabat pemerintah melakukan korupsi. Oleh karena itu, pengelolaan pemerintah daerah harus akuntabel dan diawasi (checks and balances) untuk memastikan bahwa pengelolaan dilakukan dengan penuh kepatuhan dengan menerapkan Sistem Pengendalian Intern. Pengendalian Intern yang bagus akan menciptakan akuntabilitas publik yang baik. Setiawan (2012) mengemukakan bahwa semakin baik akuntabilitas suatu pemerintah daerah berarti semakin sedikit terjadinya permasalahan information asymmetry dan semakin sedikit peluang terjadinya fraud oleh pihak pemerintah daerah (agent). Penelitian Adefila and Adeoti (2006) menemukan bahwa akuntabilitas merupakan metode yang paling 
baik untuk mencegah fraud. Idris (2012) dalam penelitiannya menemukan pengaruh tidak langsung pengendalian intern terhadap fraud bila melalui akuntabilitas. Berdasarkan penelitian sebelumnya tersebut, maka hipotesis ketiga yang akan diuji dalam penelitian ini adalah:

H3 : Terdapat pengaruh tidak langsung antara sistem pengendalian intern dan pencegahan fraud melalui akuntabilitas publik.

\section{METODE PENELITIAN}

\section{Populasi dan Sampel Penelitian}

Populasi yang digunakan dalam penelitian ini adalah auditor pemerintah yang bekerja di Kantor Inspektorat Kota Magelang, Kabupaten Magelang, Purworejo, Temanggung dan Wonosobo. Wilayah tersebut juga bisa dijangkau oleh peneliti sehingga kuesioner akan dibagikan langsung oleh peneliti kepada responden. Metode pengambilan sampel dalam penelitian ini dilakukan dengan metode purposive sampling dengan kriteria: (1) auditor yang mempunyai pengalaman kerja minimal dua tahun, dengan pertimbangan bahwa auditor yang telah memiliki masa kerja $\geq 2$ tahun dianggap telah memiliki waktu dan pengalaman dalam mengaudit, terutama pengawasan internal, (2) Pendidikan terakhir auditor minimal S1, (3) Pemerintah daerah tempat auditor bekerja terdapat kasus fraud dan tidak mendapatkan opini Wajar Tanpa Pengecualian atas Laporan Keuangan Pemerintah Daerah dari BPK RI.

\section{Pengukuran Variabel}

\section{Pencegahan Fraud}

Pencegahan fraud adalah aktivitas yang dilaksanakan manajemen dalam hal penetapan kebijakan, sistem dan prosedur yang membantu meyakinkan bahwa tindakan yang diperlukan sudah dilakukan untuk dapat memberikan keyakinan memadai terhadap keandalan pela- poran keuangan, efektivitas dan efisiensi operasi serta kepatuhan terhadap hukum \& peraturan yang berlaku. Pencegahan fraud ini diukur menggunakan tiga indikator dan dioperasionalisasikan menjadi sembilan item pertanyaan. Pertanyaan tersebut terdiri dari 4 pertanyaan mengenai pengembangan budaya yang menghargai kejujuran dan nilai-nilai etika yang tinggi, 3 pertanyaan mengenai penerapan dan evaluasi proses pengendalian anti fraud, dan 2 pertanyaan mengenai pengembangan proses pengawasan (overright process). Instrumen yang digunakan untuk mengukur pencegahan fraud ini diadopsi dari penelitian Purwanto (2010). Pencegahan fraud diukur dengan skala likert lima point yaitu: (1) sangat tidak setuju sampai dengan (5) sangat setuju.

\section{Pengendalian Intern}

Pengendalian intern yang dimaksud dalam penelitian ini adalah proses yang integral pada tindakan dan kegiatan yang dilakukan secara terus menerus oleh pimpinan dan seluruh pegawai untuk memberikan keyakinan memadai atas tercapainya tujuan organisasi melalui kegiatan yang efektif dan efisien, keandalan pelaporan keuangan, pengamanan aset negara, dan ketaatan terhadap peraturan perundang-undangan (Peraturan Pemerintah No. 60 Tahun 2008). Lima dimensi dari variabel pengendalian intern terdiri atas: lingkungan pengendalian, penaksiran risiko, aktivitas pengendalian, informasi dan komunikasi serta pemantauan (monitoring). Pengendalian Intern diukur dengan skala likert lima point yaitu: (1) sangat tidak setuju sampai dengan (5) sangat setuju (Kumalasari, 2011).

\section{Akuntabilitas Publik}

Akuntabilitas publik dalam penelitian ini merupakan kewajiban pihak pemegang amanah (pemerintah) untuk memberikan pertanggungjawaban, menyajikan, melaporkan, dan mengungkapkan segala aktivitas dan kegiatan yang menjadi tanggungjawabnya kepada pihak 
pemberi amanah (masyarakat). Instrumen yang digunakan untuk mengukur variabel ini diadopsi dari kuesioner yang digunakan dalam penelitian Kristianto (2011). Variabel ini diukur dengan menggunakan empat indikator yaitu: (1) akuntabilitas terhadap hukum dan peraturan perundang-undangan dengan 4 item pertanyaan, (2) akuntabilitas terhadap prosedur, proses dan pelakasanaan kegiatan dengan 5 item pertanyaan, (3) akuntabilitas program kegiatan dengan 3 item pertanyaan dan (4) akuntabilitas atas pilihanpilihan kebijakan yang telah dibuat dengan 3 item pertanyaan. Akuntabilitas Publik diukur dengan skala likert lima point yaitu: (1) sangat tidak setuju sampai dengan (5) sangat setuju.

\section{Jenis dan Sumber Data}

Data yang digunakan dalam penelitian ini adalah data primer, yaitu data yang diperoleh dari sumber atau tempat penelitian secara langsung. Data primer dalam penelitian ini diperoleh melalui kuesioner yang dilakukan dengan cara menyebarkan kuesioner untuk dijawab oleh responden yang berisi tentang variabel yang diteliti. Dalam penelitian ini dilakukan pengelolaan kuesioner untuk mendapatkan data yang diperlukan.

\section{Metode Analisis Data \\ Uji Validitas dan Reliabilitas}

Uji validitas digunakan untuk mengukur sah atau valid dan tidaknya suatu kuesioner. Kuisioner dikatakan valid jika pertanyaan pada kuisioner mampu untuk mengungkapkan sesuatu yang akan diukur oleh kuisioner tersebut (Ghozali, 2011:52). Pengujian validitas dilakukan dengan uji Confirmatory Factor Analysis (CFA). Kuesioner dikatakan valid jika nilai KaiserMeyer-Olkin Measure of Sampling Adequacy (KMO MSA) lebih besar dari 0.50 atau dengan tingkat signifikansinya dibawah 0.05 .

Uji reliabilitas adalah alat untuk mengukur suatu kuesioner yang merupakan indikator dari variabel atau konstruk.Suatu kuesioner dikatakan reliabel atau handal jika jawaban seseorang terhadap pertanyaan adalah konsisten atau stabil dari waktu ke waktu. Uji realibilitas dimaksud untuk mengetahui sejauh mana hasil pengukuran tetap konsisten, apabila dilakukan pengukuran dua kali atau lebih terhadap gejala yang sama. Pengujian reliabilitas dalam penelitian ini untuk menilai sejauh mana suatu pengukuran dapat dipercaya yang konsisten atau stabil dari waktu ke waktu. Pengujian dilakukan dengan menghitung croanbach's alpha dari masing-masing instrumen dalam suatu variabel. Instrumen yang dipakai dalam variabel tersebut dikatakan handal/reliabel jika memberikan nilai croanbach's alpha lebih dari 0,70. (Ghozali, 2011:47).

\section{Uji Analisis Statistik}

Untuk melakukan pengujian hipotesis yang telah dirumuskan, yaitu untuk mengetahui pengaruh langsung serta tidak langsung tentang Pengendalian Intern (X1) dan Akuntabilitas Publik (X2) terhadap Pencegahan Fraud (Y) menggunakan alat regresi linier berganda, persamaan regresi berganda adalah sebagai berikuti:

$\mathrm{Y}=\alpha+\beta 1 \mathrm{X} 1+\beta 2 \mathrm{X} 2+\mathrm{e}$

Di mana:

Y $\quad=$ Pencegahan Fraud

$\alpha \quad=$ konstanta

$\beta \quad=$ koefisien regresi

$\mathrm{X} 1=$ Pengendalian Intern

$\mathrm{X} 2=$ Akuntabilitas Publik

e $\quad=$ error

Untuk menguji pengaruh variabel intervening, dalam penelitian ini adalah Akuntabilitas Publik, digunakan metode analisis jalur (path analysis). Analisis jalur ini merupakan perluasan dari analisis regresi linear berganda, atau analisis jalur adalah penggunaan analisis regresi untuk menaksir hubungan kausalitas antar variabel (model causal) yang telah ditetapkan sebelumnya berdasarkan teori. 


\section{HASIL PENELITIAN DAN PEMBAHASAN \\ Deskripsi Objek Penelitian}

Sampel penelitian ini adalah para auditor internal pemerintah yang bekerja di Kantor InspektoratKotaMagelang, Kabupaten Magelang, Kabupaten Purworejo, Kabupaten Temanggung, dan Kabupaten Wonosobo. Teknik pengambilan sampel dilakukan dengan metode purposive sampling. Kuesioner yang disebar sebanyak 75, jumlah ini diperoleh dari jumlah auditor pada tiap-tiap daerah. Kuesioner kembali sebanyak 66 responden atau sebesar $88 \%$, kuesioner yang tidak sesuai dengan kriteria sehingga tidak dapat diolah sebanyak 7 responden. Jumlah kuesioner yang dapat diolah sebanyak 59 responden atau $78,67 \%$.

Berdasarkan data profil responden, sebagian besar responden yang paling banyak berpartisipasi adalah laki-laki sebanyak 34 orang (57.63\%). Dari pengelompokan usia, responden yang paling banyak berpartisipasi adalah yang berusia antara 36-45 tahun sebanyak 27 orang (45.76\%). Dilihat dari masa kerja responden yaitu lama di inspektorat, sebagian besar masa kerja responden antara 11-15 tahun sebanyak 21 orang (35.59\%). Sedangkan dilihat dari tingkat pendidikan responden, sebagian besar berpendidikan S1 sebanyak 46 orang (77.97\%).

\section{Hasil Uji Validitas Data}

Uji validitas digunakan untuk mengukur sah atau valid dan tidaknya suatu kuesioner. Kuisioner dikatakan valid jika pertanyaan pada kuisioner mampu untuk mengungkapkan sesuatu yang akan diukur oleh kuisioner tersebut (Ghozali, 2011:52). Hasil dari analisis ini dapat dilihat pada tabel dibawah ini:

\section{Tabel 1}

\section{Uji Validitas Data SPI}

KMO and Bartlett's Test

\begin{tabular}{|c|c|c|}
\hline Kaiser-Meyer-O1 & ure of Sampling Ade & .737 \\
\hline $\begin{array}{l}\text { Bartlett's Test of } \\
\text { Sphericity }\end{array}$ & Approx. Chi-Square & 619.149 \\
\hline & $\begin{array}{l}\text { Df } \\
\text { Sig. }\end{array}$ & $\begin{array}{l}171 \\
.000\end{array}$ \\
\hline
\end{tabular}

Sumber : hasil olah data, 2013
Pada tabel 1 diatas dapat dilihat bahwa nilai KMO MSA variabel SPI sebesar 0.737 atau $73.7 \%$, hal ini menunjukkan bahwa instrumen SPI valid karena memiliki nilai KMO MSA lebih dari 0.50 .

\section{Tabel 2}

\section{Uji Validitas Data AP} KMO and Bartlett's Test

\begin{tabular}{llr}
\hline \multicolumn{3}{c}{ Kaiser-Meyer-Olkin Measure of Sampling Adequacy. } \\
\hline Bartlett's Test of & Approx. Chi-Square & .822 \\
Sphericity & & 585.770 \\
& Df & 91 \\
& Sig. & .000 \\
\end{tabular}

Sumber : hasil olah data, 2013

Pada tabel 2 diatas dapat dilihat bahwa nilai KMO MSA variabel AP sebesar 0.822 atau $82.2 \%$, hal ini menunjukkan bahwa instrumen AP dalam penelitian ini valid karena memiliki nilai KMO MSA lebih dari 0.50 .

\section{Tabel 3}

\section{Uji Validitas Data PF}

KMO and Bartlett's Test

\begin{tabular}{llr}
\hline \multicolumn{2}{l}{ Kaiser-Meyer-Olkin Measure of Sampling Adequacy. } & .859 \\
\hline Bartlett's Test of & Approx. Chi-Square & 306.862 \\
Sphericity & & 36 \\
& Df & .000 \\
\hline
\end{tabular}

Sumber : hasil olah data

Pada tabel 3 diatas dapat dilihat bahwa nilai KMO MSA variabel PF sebesar 0.859 atau $85.9 \%$, hal ini menunjukkan bahwa instrumen PF dalam penelitian ini valid karena memiliki nilai KMO MSA lebih dari 0.50 .

\section{Hasil Uji Reliabilitas Data}

Suatu kuesioner dikatakan reliabel atau handal jika jawaban seseorang terhadap pertanyaan adalah konsisten dari waktu ke waktu. Pengujian reliabilitas data menggunakan alat bantu statistik, yaitu program SPSS dengan metode Cronbach Alpha. Suatu konstruk atau variabel dikatakan reliabel jika memberikan nilai Cronbach Alpha > 0,70 (Nunnally, 1994 dalam Ghozali, 2011:48). 
Tabel 4

Pengujian Reliabilitas

\begin{tabular}{lccc}
\hline \multicolumn{1}{c}{ Variabel } & Pertanyaan & $\begin{array}{c}\text { Cronbach } \\
\text { Alpha }\end{array}$ & Keterangan \\
\hline Pengendalian Intern & P1-P19 & 0.900 & Reliabel \\
Akuntabilitas Publik & P1-P14 & 0.923 & Reliabel \\
Pencegahan Fraud & P1-P9 & 0.897 & Reliabel \\
\hline
\end{tabular}

Sumber: Data primer diolah, 2013

Hasil pengujian reliabilitas yang terlihat pada tabel 4 menunjukkan bahwa variabel pengendalian intern, akuntabilitas publik dan pencegahan fraud memiliki nilai Cronbach Alpha $>0,70$. Jadi dapat disimpulkan bahwa semua variabel instrumen yang digunakan dalam penelitian ini reliabel.

\section{Pengujian Hipotesis dan Pembahasan Analisis Hipotesis 1}

Hipotesis pertama menduga bahwa pengendalian intern berpengaruh positif terhadap akuntabilitas publik. PP Nomor 60 Tahun 2008 menerangkan bahwa pengendalian intern terdiri dari lima unsur. Kelima unsur pengendalian intern dalam penelitian ini merupakan pengendalian intern pada SKPD menurut persepsi dan penilaian auditor internal inspektorat se-eks Karesidenan Kedu. Untuk menguji variabel bebas secara parsial berpengaruh terhadap variabel terikat maka dilakukan uji t. Berdasarkan hasil pengujian hipotesis, didapat tingkat signifikansi $0.000(<0.05)$ dan nilai t hitung 8.810, sehingga diperoleh bukti bahwa pengendalian intern berpengaruh positif terhadap akuntabilitas publik. Hal ini berarti Ha diterima dan $\mathrm{HO}$ ditolak. Hal ini menunjukkan bahwa semakin baik pengendalian intern di suatu instansi maka akan meningkatkan akuntabilitas publik. Dari tampilan output SPSS, besarnya Adjusted $R^{2}$ sebesar 0.569 , hal ini berarti bahwa akuntabilitas publik dijelaskan oleh pengendalian intern sebesar 56.9\% sedangkan sisanya sebesar $43.1 \%$ dijelaskan variabel lain diluar model penelitian. Hasil penelitian Ini sesuai dengan penelitian Idris (2012).
Tabel 5

Hasil Pengujian Hipotesis 1

\begin{tabular}{cccc}
\hline $\begin{array}{c}\text { Variabel } \\
\text { Independen }\end{array}$ & $\begin{array}{c}\text { Koefisien } \\
\text { Regresi }(\beta)\end{array}$ & t-test & Sig. \\
\hline Pengendalian Intern & 0.656 & 8.810 & 0.000 \\
Konstanta & 5.550 & & \\
\hline
\end{tabular}

Var. Dependen: AP

Sumber: Data primer diolah 2013

\section{Hipotesis 2}

Hipotesis kedua menduga bahwa pengendalian intern berpengaruh positif terhadap pencegahan fraud. Berdasarkan hasil pengujian hipotesis, didapat tingkat signifikan 0.000 $(<0.05)$ sehingga diperoleh bahwa pengendalian intern berpengaruh positif terhadap pencegahan fraud. Ini berarti hipotesis dua $\left(\mathrm{H}_{2}\right)$ penelitian ini diterima, bahwa semakin tinggi pengendalian intern maka pencegahan fraud akan semakin meningkat. Pengendalian intern mempunyai peranan sangat penting dalam hal mencegah praktik fraud. Menurut persepsi dan penilaian auditor internal pemerintah yang berperan mengawasi kinerja pemerintah daerah, SKPD di wilayah kerja masing-masing telah melaksanakan kelima unsur pengendalian intern dengan cukup baik. Hal ini berdasarkan hasil kuesioner kepada responden yang memperlihatkan bahwa rata-rata responden menjawab setuju pada pernyataan pengendalian intern. Besarnya Adjusted $R^{2}$ sebesar 0.758 , hal ini berarti bahwa pencegahan fraud dijelaskan oleh pengendalian intern sebesar $75.8 \%$ sedangkan sisanya sebesar $24.2 \%$ dijelaskan variabel lain diluar model penelitian.

Menurut Siti dan Ely (2010:64) dalam Kumalasari (2011) menyatakan bahwa pengendalian intern yang secara khusus ditujukan untuk menangani fraud merupakan suatu sistem dengan proses dan prosedur yang bertujuan khusus, dirancang dan dilaksanakan untuk tujuan utama yaitu mencegah dan menghalangi terjadinya kecurangan. Hasil penelitian ini sesuai dengan hasil penelitian Fajarina,dkk (2012), Kumalasari (2011), dan Hermiyetti (2010) yang 
menunjukkan bahwa pengendalian intern yang terdiri dari lima komponen, yaitu lingkungan pengendalian, penilaian risiko, kegiatan pengendalian, informasi dan komunikasi, serta pemantauan terbukti secara signifikan berpengaruh positif terhadap pencegahan fraud.

\section{Tabel 6}

Hasil Pengujian Hipotesis 2

\begin{tabular}{cccc}
\hline Variabel & $\begin{array}{c}\text { Koefisien Regresi } \\
(\beta)\end{array}$ & t-test & Sig. \\
Independen & 0.269 & 4.504 & 0.000 \\
\hline Pengendalian Intern & -3.639 & & \\
Konstanta & & &
\end{tabular}

Var. Dependen: PF

Sumber: Data primer diolah 2013

\section{Hipotesis 3}

Hipotesis ketiga menduga bahwa pengendalian intern melalui akuntabilitas publik memengaruhi pencegahan fraud. Hipotesis ketiga ini diuji dengan menggunakan koefisien jalur yang merupakan standardized koefisien regresi. Koefisien jalur dihitung dengan membuat dua persamaan struktural yaitu persamaan regresi yang dihipotesiskan. Dalam hal ini ada dua persamaan:

Akuntabilitas Publik $=$ b1 pengendalian intern $+\mathrm{e} 1$

Pencegahan Fraud $=$ b1 pengendalian intern+b2 akuntabilitas publik+e2

Persamaan pertama dilakukan dengan regresi sederhana dengan AP sebagai variabel dependen (Y), dan PI sebagai variabel independen (X). Sedangkan persamaan kedua dilakukan dengan regresi berganda dengan PF sebagai variabel dependen (Y) dan variabel independen adalah PI (X1) dan AP (X2). Hasil dari koefisien jalur ditampilkan dalam gambar dibawah ini:

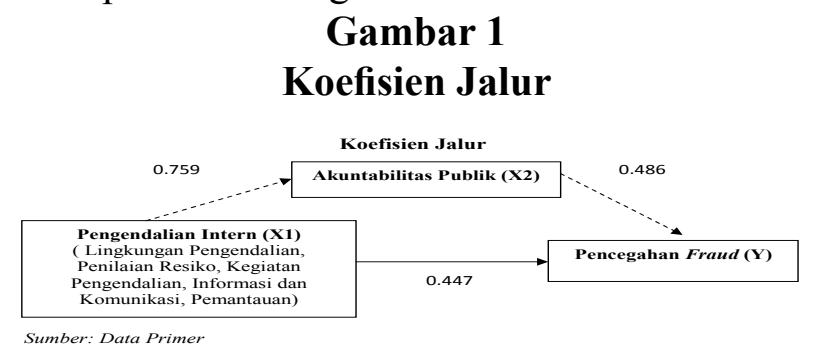

Sumber: Data Primer
Hasil output SPSS perhitungan regresi berganda dapat diketahui nilai standardized beta pengendalian intern pada persamaan satu sebesar 0.759 dan signifikan pada 0.000 yang berarti pengendalian intern mempengaruhi akuntabilitas publik. Nilai koefisien standardized beta 0.759 merupakan nilai path atau jalur p2. Pada persamaan regresi dua nilai standardized beta untuk pengendalian intern 0.447 dan akuntabilitas publik 0.486 semuanya signifikan pada 0.000 . Nilai standardized beta pengendalian intern 0.447 merupakan nilai jalur path p1 dan nilai standardized beta akuntabilitas publik 0.486 merupakan nilai jalur path p3.

Hasil analisis jalur menunjukkan bahwa pengendalian intern dapat berpengaruh langsung terhadap pencegahan fraud dan dapat juga berpengaruh tidak langsung yaitu dari pengendalian intern ke akuntabilitas publik (sebagai intervening) lalu ke pencegahan fraud. Besarnya pengaruh langsung adalah 0.447 sedangkan besar pengaruh tidak langsung yaitu 0.369 .

\section{KESIMPULAN DAN SARAN}

\section{Kesimpulan}

Hasil penelitian menemukan bukti bahwa pengendalian intern berpengaruh positif terhadap akuntabilitas publik dan pencegahan fraud. Analisis jalur dengan menggunakan koefisien jalur menunjukkan bahwa pengendalian intern dapat berpengaruh langsung terhadap pencegahan fraud dan dapat juga berpengaruh tidak langsung yaitu dari pengendalian intern ke akuntabilitas publik (sebagai intervening) lalu ke pencegahan fraud.

Keterbatasan dalam penelitian ini adalah Objek penelitian ini terbatas pada auditor Inspektorat Kota/Kabupaten se-eks Karesidenan Kedu. Hal ini memungkinkan perbedaan hasil pembahasan maupun kesimpulan untuk objek penelitian yang berbeda. Selain itu penelitian 
ini meneliti variabel pengendalian intern secara keselurahan yang terdiri dari lima dimensi sebagai satu variabel, sehingga hasilnya kurang spesifik.

\section{Saran}

Untuk penelitian mendatang, peneliti dapat menggunakan responden dari instansi terkait seperti kepala dan staf bagian SKPD untuk mengetahui hasil yang lebih maksimal, mengingat penelitian ini adalah persepsi dari auditor internal Inspektorat selaku pengawas pemerintah. Penelitian selanjutnya dapat menjabarkan komponen pengendalian intern yaitu lingkungan pengendalian, penilaian risiko, kegiatan pengendalian, informasi dan komunikasi, serta pemantauan sebagai variabel tersendiri agar hasilnya dapat lebih spesifik.

\section{DAFTAR PUSTAKA}

Adefila, J.J and J.O Adeoti. 2006. The Essence of Accountability in Fraud Prevention and Control: Borno State Ministry of Finance's Perception. Book of readings titled Topics in Modem Management.

Antarajateng.com. 2012, 7 Mei. Mantan Kepala Dinas Pendidikan Wonosobo Divonis Tiga Tahun. (http://jateng.antaranews. com, diakses 29 Desember 2012).

Berita21.com. 2013, 7 Maret. Oknum Pejabat Diknas Diduga Selewengkan Dana SMK. ( http://nasional.berita21.com, diakses 29 Maret 2013).

Chan, James L. 2003. Government Accounting: An Assessment of Theory, Purposes and Standards. Public Money \& Management, January.

Committee of Sponsoring Organizations of Teadway Commission (COSO). 1992. Internal Control Integrated Framework. New York: AICPA Publication.
Fajarina, Wirda, Darwanis dan Usman Abu Bakar. 2012. Pengaruh Lingkungan Pengendalian, Penilaian Risiko, Kegiatan Pengendalian, Informasi dan Komunikasi, Serta Pemantauan Terhadap Pencegahan Fraud Pengadaan Barang/Jasa Pada SKPD di Pemerintah Aceh. Jurnal Akuntansi Pascasarjana Universitas Syiah Kuala, Vol.1 No.1 Agustus, hal 1-20.

Ghozali, Imam. 2011. Aplikasi Analisis Multivariate dengan Program IBM SPSS 19. Cetakan V. Semarang: Badan Penerbit Universitas Diponegoro. 2010, 18 Februari. Kasus Korupsi Dana Alkes Purworejo. (http:// infokorupsi.com, diakses 29 Desember 2012).

Idris, Kartini Hanafi. 2012. Dimensi Internal Control dan Internal Auditor dalam Accountability dan Fraud Prevention. Disertasi. Makassar: Unhas. (http:// repository.unhas.ac.id, diakses 23 Juni 2013)

Jensen, Michael $\mathrm{C}$ and William $\mathrm{H}$ Meckling. 1976. Theory of the Firm: Managerial Behavior, Agency Costs and Ownership Structure. Journal of Financial Economics, October, V.3, No. 4, pp. 305-360.

Kumalasari, Nova Riska. 2011. Pengaruh Pengendalian Intern Terhadap Pencegahan Fraud Pada Pemerintahan Kota Bandung. Skripsi. Bandung: Program Studi Akuntansi Fakultas Ekonomi Universitas Komputer Indonesia.( http:// elib.unikom.ac.id, diakses 26 November 2012)

Mahsun, Mohammad. 2009. Pengukuran Kinerja Sektor Publik Edisi 1. Yogyakarta: BPFE.

Mardiasmo. 2005. Akuntansi Sektor Publik Edisi 2. Yogyakarta: Andi. 
Matsumura, Ella Mae and Robert R Tucker. 1992. Fraud Detection: A Theoritical Foundation. The Accounting Review. Vol 67 No.4; pp 753 - 782.

Moe, Terry M. 1984. The New Economics of Organization. American Journal of Political Science. Vol 28 No 4, November, pp 739 - 777.

Nurdin, Edwardsyah. 2012. Peran Pengawasan Intern dalam Mencegah Fraud. SOLUSI Vol 2 Maret 2012 hal 12-13.

Peraturan Pemerintah No. 60 Tahun 2008 tentang Sistem Pengendalian Intern Pemerintah.

Rachman, Arpan. 2012. Cegah Fraud di Instansi Pemerintah. (Online). ( http:// kampus.okezone.com/ $\mathrm{read} / 2012 / 10 / 24 / 373 / 708852 / \mathrm{cegah}-$ fraud-di-instansi-pemerintah, diakses 10 Januari 2013).

Reinstein, Alan and Bayou Mohamed E. 1998. A Comprehensive Structure to Help Analyse, Detect and Prevent Fraud.
Working Paper. (Online). (http://dx.doi. org/10.2139/ssrn.172055, diakses 4 April 2013).

Rezaee, Zabihollah and Richard Riley. 2010. Financial Statement Fraud: Prevention and Detection $2^{\text {nd }}$ Edition. Canada: by John Wiley \& Sons, Inc.

Ruslan. 2011. Penerapan Sistem Pengendalin Intern Pemerintah di Lingkungan Instansi Pemerintah. (Online). (http:// ruslan.web.id, diakses 4 Desember 2012).

Smith, Reed, Samuel Tiras, and Stan Vichitlekarn. 1997. The Interaction Between Internal Control Assessment and Substantive Testing in Audits for Fraud. Working Paper. (Online). (http://dx.doi. org/10.2139/ssrn.70811, diakses 4 April 2013).

Suaramerdeka.com. 2013, 5 Februari. Kepala Dinas Kesehatan Magelang Dihukum Setahun. (http://www.suaramerdeka. com, diakses 25 Februari 2013). 